\title{
Kontestasi Kuasa Kepemimpinan Formal dengan Informal dalam Kebijakan Publik dan Politik Keseharian
}

\author{
Yeby Ma'asan Mayrudin ${ }^{1 *}$, Nabilla Amalia Husna ${ }^{1}$, Fanny Rosye Yuliati ${ }^{1}$
}

${ }^{1}$ Program Studi Ilmu Pemerintahan, Universitas Sultan Ageng Tirtayasa, 42121, Serang, Indonesia

\section{Info Artikel \\ Dikirim: Mei 22, 2020 \\ Diterima: Jun 26, 2020 \\ Dipublikasi: Jul 04, 2020}

Kata Kunci:

Kepemimpinan Informal;

Desa Adat;

Shadow State.

Koresponden:

Yeby Ma'asan

Mayrudin,

Jurusan Ilmu Pemerintahan

Universitas Sultan Ageng

Tirtayasa

Email:

yeby@untirta.ac.id

Cantuman Sitasi:

Mayrudin, Yeby Ma'asan, et.al. 2020. Kontestasi Kuasa Kepemimpinan Formal dengan Informal dalam Kebijakan Publik dan Politik Keseharian. Journal of Political Issues. 2(1); 01-09. Doi:

https://doi.org/10.33019/ipi.v $\underline{2 \mathrm{i} 1.30}$

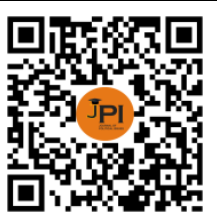

DOI:

https://doi.org/10.33019/jpi.v $\underline{2 i 1.30}$

Lisensi:

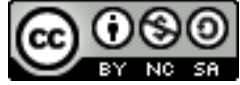

Attribution-NonCommercialShareAlike 4.0 International (CC- BY-NC-SA 4.0)

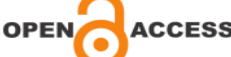

\begin{abstract}
ABSTRAK
Abstract This article discusses the dynamics of the contestation of the power of the village head as a formal leader with Abah Olot who is the traditional leader as an informal leader in public policies and daily politics in the traditional village of Guradog, Curugbitung District, Lebak Regency, Banten Province. The issue shows the existence of power contestation between actors. This intersection results in a battle of dominative power between the two actors. Therefore, the research team traced the practice of power relations that occurred to be able to be used as a reflection to explain the problematics. In investigating this phenomenon, the research team used the "Leadership" and "Shadow State" framework which was used as an analysis tool. The research method uses descriptive qualitative method. This type of method is able to manifest descriptive data related to the subject matter in this article. As a result, this paper proves the manifestation of the informal leader's hegemonic power of formal leadership. Shadow state practices of the power of informal actors who are able to "drive" formal structural actors are manifested in the case of actualization of public policies and daily politics in the tradisional village of Guradog.
\end{abstract}

Abstrak Artikel ini membedah tentang dinamika kontestasi kuasa kepala desa sebagai pemimpin formal dengan Abah Olot yang merupakan kepala adat sebagai aktor informal dalam kebijakan publik dan politik keseharian di Desa Adat Guradog, Kecamatan Curugbitung, Kabupaten Lebak, Provinsi Banten. Persoalan tersebut menunjukkan adanya persilangan kontestasi kuasa antara aktor. Interseksi ini memunculkan pertarungan kuasa dominatif di antara kedua aktor tersebut. Oleh karena itu, tim penulis menelusuri praktik relasi kuasa yang terjadi agar mampu dijadikan sebagai refleksi untuk membenahi problematika itu. Dalam menyelisik fenomena tersebut, tim penulis menggunakan kerangka teori Kepemimpinan dan Shadow State yang dimanfaatkan sebagai pisau analisa. Adapun metode penelitiannya memakai metode kualitatif deskriptif. Metode jenis ini mampu mengejawantahkan data deskriptif terkait dengan pokok persoalan dalam artikel ini. Alhasil, tulisan ini membuktikan manifestasi kuasa hegemonik pemimpin informal terhadap kepemimpinan formal. Praktik shadow state atas kuasa aktor informal yang mampu "menyetir" aktor struktural formal pemerintahan terejawantahkan pada kasus aktualisasi kebijakan publik dan politik kesehariannya di desa adat Guradog.

Tentang Penulis:

Yeby Ma'asan Mayrudin, menyelesaikan studi (S2) Ilmu Politik dan Pemerintahan UGM Yogyakarta pada tahun 2015. Saat ini penulis merupakan dosen tetap di Jurusan Ilmu Pemerinthaan Universitas Sultan Ageng Tirtayasa.

Nabilla Amalia Husna, merupakan Mahasiswa (S1) Jurusan Ilmu Pemerintahan, Universitas Sultan Ageng Tirtayasa.

Fanny Rosye Yuliati, merupakan Mahasiswa (S1) Jurusan Ilmu Pemerintahan, Universitas Sultan Ageng Tirtayasa. 


\section{PENDAHULUAN}

Fokus artikel ini menyelisik tentang pertautan relasi kuasa antara pemimpin formal (aparatur desa) dengan pemimpin informal (tokoh adat) dalam kebijakan-kebijakan publik meliputi juga politik keseharian (daily activities) di Desa Adat Guradog. Dalam ranah kontestasi aktor formal dengan informal yang kerap mengemuka adalah pertarungan kuasa dominatif di antara kedua aktor tersebut. Secara kasat mata memang terlihat bahwa kuasa pemimpin formal faktanya memiliki legitimasi yuridis dan kewenangan yang sudah diatur secara formalistik dalam perundang-undangan. Meski demikian kondisi objektif yang ada di lapangan, para aktor informal kerap mengejawantah memiliki kuasa dominatif bahkan hegemonik di aras kekuasaan pemerintahan.

Salah satu penelitian yang membenarkan kondisi seperti demikian itu adalah penelitian yang dikerjakan oleh Syarif Hidayat mengenai dinamika politik lokal di Banten. Hidayat dalam penelitiannya menyebut bahwa kebijakan-kebijakan proyek atau pembangunan di kawasan Banten tidak lepas dari peran kunci sosok Chasan Sochib sebagai informal leader (Hidayat, 2007). Menilik konsepsi informal leader mengacu pada pendapat Koentjaraningrat adalah pemimpin non-pejabat resmi negara, artinya bukan pengangkatan langsung oleh pemerintah dan suksesinya tidak melalui prosedur legal formal seperti pemilu (Rostiyati, 2009). Akan tetapi pemimpin tipe ini dalam beberapa kasus kerap memiliki kuasa yang lebih dominatif dan hegemonik dibanding kuasa pemimpin formal seperti fenomena kuasa Sochib yang merupakan ayah Ratu Atut Chosiyah adalah sebagai aktor utama terpilihnya sang anak menjadi Wakil Gubernur kemudian Gubernur Banten.

Hal penting lain untuk ditandaskan juga bahwa sosok pemimpin formal pun seyogyanya memiliki sisi dominatif, karena tanpa pengesahan -baik berupa tanda tangandarinya sebuah kebijakan tidak mungkin terealisasi. Dari perspektif ini dapat menunjukkan bahwa aras kekuasaan tetap menjadi kuasa sang formal leader. Maka dari isu-isu di atas itu tim peneliti mencoba membedah aktualisasi kuasa aktor formal leader yang terfokus pada kepala desa dengan kepala adat sebagai informal leader di desa Guradog.

Desa Guradog adalah salah satu desa di Kecamatan Curugbitung terletak di Kabupaten Lebak, Provinsi Banten. Bukan tanpa alasan desa ini masuk dalam daftar sebagai desa adat. Hal itu dikarenakan eksistensi sebuah kasepuhan atau komunitas adat yang dikenal dengan sebutan kaolotan. Istilah itu bersandar pada penjabaran Adimihardja yang dikutip Rosyadi merujuk pada suatu sistem kepemimpinan atas kelompok sosial budaya yang berasas pada adat atau kebiasaan para sesepuh atau kakolot (nenek moyang) terdahulu. Kekhasan desa adat yang lainnya yaitu kehadiran kepala adat atau yang dikenal dengan sebutan abah Olot sebagai pemimpin informal di desa adat Guradog (Rostiyati, 2009).

Kepala adat dimaknai oleh Soepomo sebagai pemimpin masyarakat atau ketua suatu keluarga besar di masyarakat lokal. Ia mempunyai peranan signifikan sebagai pembinaan masyarakat dan bertanggungjawab menjaga perdamaian dengan menjalankan hukum adat atau kebiasaan yang sudah membumi di tengah masyarakat (Soepomo, 1979). Adapun suksesi kepemimpinan Olot sebagai kepala adat desa Guradog bersandar pada tulisan Rostiyati dan Purnama ditentukan berdasar pada garis keturunan yang jatuh kepada keturunan laki-laki (Purnama, 2009; Rostiyati, 2009). Demikian menunjukkan adanya ancang-ancang dan kepatutan bagi sang penerus dalam rangka pengalihan kekuasaan dari abah Olot. Sang Olot berperan aktif dalam beberapa hal, seperti dalam menyelesaikan persoalan-persoalan sosial yang ada di tengah masyarakat adat Guradog, pemimpin dalam penyelenggaraan kegiatan musyawarah, upacara ritual adat, meminta saran, arahan, nasehat dan sebagai suri tauladan bagi masyarakat dalam melaksanakan tatanan ataupun cara kehidupan sehari-hari. Masyarakat desa adat ini sudah terpatri dalam benaknya bahwa abah Olot kerap dimanifestasi sebagai solusi atas persoalan-persoalan yang tengah dialami oleh masyarakat.

Namun bila bersandar pada perspektif institusionalisme (varian old institutionalism) yang dijabarkan oleh Marsh dan Stoker dapat diformulasikan bahwa pemimpin formal 
memiliki kekuasaan dan kewenangan yang terlegitimasi karena melalui prosedural legal formal yang sudah ditetapkan melalui perundang-undangan atau aturan pemerintah lainnya. Di samping itu, kuasa administratif dinilai juga sebagai alat kekuasaan aktor formal dalam men-subordinasi pihak lain. Maka dalam perspektif ini, kepemimpinan kepala desa Guradog seyogyanya juga memiliki kuasa dan peran dominan dalam dalam tata kelola pemerintahan dan kemasyarakatan di desanya (Marsh \& Stoker, 2010).

Dari penjabaran beberapa problematika di atas, terlihat persilangan isu penting antara kontestasi kuasa pemimpin formal dengan pemimpin informal dalam kebijakan-kebijakan publik maupun politik keseharian di desa adat Guradog. Bagaimana tidak bila melihat interseksi tersebut, muncul anggapan yang tendensius bahwa kebijakan hanya dipraktikkan oleh kuasa para elit yang jangan-jangan berorientasi pada kepentingan elitis. Akhirnya mengeksklusi kemaslahatan segenap warga desa. Oleh karena itu, tim penulis percaya bahwa pembongkaran fenomana tersebut akan mampu menyajikan realitas yang sesungguhnya terjadi dan mampu menjadi refleksi untuk membenahi problematika tersebut.

\section{METODE PENELITIAN}

Metode yang digunakan dalam penelitian ini ialah metode kualitatif deskriptif. Digunakannya penelitian kualitatif berguna bagi tim peneliti dalam memahami, menggali, dan mengungkap fenomena tertentu dari objek penelitian. Penelitian kualitatif memang bertujuan untuk mendapat suatu gambaran holistik dari sebuah fenomena dari sudut pandang subjek (Tobing, 2017). Kemudian penelitian jenis ini dinilai mampu mengejawantahkan data deskriptif dalam beragam bentuk mulai dari sesuatu yang tertulis, ungkapan lisan sampai pada tindakan atau aktivitas orang atau suatu kelompok yang diteliti. Lalu teknik pengumpulan data yang tim gunakan adalah observasi, wawancara dan studi literatur. Selanjutnya data ataupun informasi yang terkumpul diklasifikasi untuk diseleksi dan direduksi sehingga dapat disajikan dan ditarik kesimpulan (Moleong, 2014) sebagai hasil telaah atas objek studi kami yaitu membedah persoalan kontestasi kuasa pemimpin formal dengan pemimpin informal dalam kebijakan publik dan politik keseharian di Desa Adat Guradog, Banten. Kontestasi kuasa kepala adat dan kepala desa (meliputi aparatur desa) dalam penelitian ini mengemuka sebagai wujud dari realitas politik untuk dimaknai sebagai aktor-aktor yang saling memengaruhi kebijakan publik dan aktivitas keseharian di desa tersebut.

\section{HASIL PENELITIAN DAN PEMBAHASAN \\ Diskursus Kepemimpinan dan Shadow State}

Sebelum menyajikan kerangka teori mengenai kepemimpinan dan shadow state, tim penulis terlebih dahulu menjabar kajian terdahulu yang terkait dengan fokus dan lokus penelitian kami. Kami mulai dari meninjau studi literatur terdahulu terkait objek penelitian di desa adat Guradog, tim penulis mendapati riset Purnama yang fokusnya melakukan eksplorasi mengenai kesenian topeng yang membudaya pada masyarakat Guradog. Riset lainnya dikerjakan oleh Rostiyati membahas mengenai peranan pemimpin informal yang memfokuskan pada peran Olot sebagai kepala adat dalam kehidupan sosial dan budaya di desa Guradog (Purnama, 2009; Rostiyati,2007).

Adapun penelitian Darmawan mengenai kepemimpinan kepala adat di desa Pekurun Tengah Lampung menunjukkan bahwa pemimpin formal yaitu kepala desa tersebut yang biasanya bukan merupakan keturunan suku asli menyebabkan implementasi programprogram pemerintah tidak berjalan maksimal (Darmawan, 2006). Selain itu, penelitian Kueng, Nasir dan Budiman yang menyelisik adanya sinergitas antara pemerintah desa dengan para pimpinan adat yang terfokus pada upaya mereka dalam mempertahankan tanah adat di desa Laham, Kabupaten Mahakam Ulu (Kueng, Nasir, \& Budiman, 2019). Terlihat bahwa penelitian-penelitian yang sudah ada sama sekali belum mengekplorasi secara mendalam tentang persoalan konstestasi kuasa pemimpin formal dengan informal dalam kebijakan- 
kebijakan publik dan politik keseharian terkhusus di desa adat Guradog. Maka dari itu, tulisan ini hadir untuk mengisi kekosongan bidang kajian kepemimpinan, kebijakan publik dan pergulatan kuasa aktor formal dengan informal.

Simplifikasi makna "kepemimpinan" berdasar atas pandangan Kartono, Keating, Heywood, dan Yukl dapat diartikan sebagai berikut, yaitu sosok individu yang punya kemahiran dan keunggulan serta kapabilitas keefektifan tindakan sehingga ia kuasa memengaruhi individu atau kelompok masyarakat agar bekerja sama dalam melaksanakan praktik-praktik tertentu ataupun untuk mencapai satu dan/atau banyak misi yang dikehendaki. Konsep tersebut akan dioperasionalisasi dengan mengerangkai dua tipe kepemimpinan sebagai berikut, yaitu (1) pemimpin formal, yakni kepala desa yang legitimasi kekuasaannya berasal dari peraturan pemerintah/negara dalam bentuk perundang-undangan, dan (2) pemimpin informal artinya pemimpin yang bukan dibentuk berdasar pada legal formal oleh pemerintah atau negara, dalam konteks tulisan ini yaitu sang kepala adat yang biasa disebut abah Olot yang memeroleh kuasa berasal dari budaya turun temurun dari nenek moyang (Heywood, 2000; Kartono, 1994; Keating, 1997; Yukl, 2007).

Selanjutnya, membincang topik relasi kuasa di aras kepemimpinan formal dan informal, tim peneliti coba mengaitkan dengan konsepsi Shadow State yang dipopulerkan oleh Barbara Harris-White, Schulte Nordholt, dan William Reno seperti yang sudah dikerangkai oleh Hidayat dan Gismar. Sederhananya konsepsi tersebut menyajikan formulasi mengenai bagaimana aktor di luar struktur formal mampu "menyetir" aktor struktural di dalam pemerintahan. Konsepsi shadow state seperti yang ditulis oleh Hidayat dan Gismar merupakan pemerintahan bayangan yang tumbuh dan berkembang semakin besar yang terkadang dominatif dan juga hegemonik. Demikian itu menimbulkan konsekuensi yang problematis yaitu memungkinkan institusi-institusi pemerintahan/negara yang legal formal sesuai ketentuan yuridis akan mengalami pelapukan. Daripada itu, konsepsi ini dimanfaatkan sebagai pisau analisa untuk membedah dinamika pergulatan kuasa pemimpin formal dengan informal di desa adat Guradog (Hidayat \& Gismar, 2010).

\section{Suksesi Kepemimpinan dan Kuasa Kepala Adat Desa Guradog}

Kepemimpinan adat berbeda dengan kepemimpinan pemerintahan yang terinstitusi legal formal. Dalam konteks kepemimpinan adat umumnya berlangsung mengikuti budaya atau adat istiadat yang sudah membumi sejak nenek moyang. Pada komunitas adat sosok pemimpinnya merupakan kepala adat. Kepala adat adalah sosok yang dipercaya sebagai tokoh sentral dalam kehidupan desa adat. Tokoh sentral berarti bahwa kepala adat memiliki berbagai peranan penting dalam menjaga keselarasan kehidupan sosial masyarakat. Kepala adat merupakan sosok yang bertanggungjawab terhadap keberlangsungan kehidupan masyarakat adat. Oleh karena itu, status kepala adat tidak diperoleh dan/atau diberikan dengan sembarang cara tapi didasarkan pada kuasa adat istiadat (faktor kultural) yang sudah membumi di desa adat Guradog.

Kepala adat di desa Guradog dikenal dengan sebutan Olot. Statusnya diperoleh melalui garis keturunan laki-laki. Penentuan status tersebut didasarkan pada kesiapan keturunan sebagai suksesor Olot selanjutnya. Dalam konteks itu, penelitian Purnama dan Rostiyati belum secara eksploratif menjabar asal usul sesepuh/nenek moyang dari sang Olot ini. Bila kita membanding dengan asal usul dari desa adat lainnya semisal Desa Urug -tertulis pada artikel Dewantara yang merupakan desa adat di Kecamatan Sukajaya Kab. Bogor dan Desa (Kasepuhan) Cisungsang, Lebak, Banten dikabarkan bahwa asal usulnya bersambung sampai pada silsilah keturunan Prabu Siliwangi. Namun asal usul Olot sebagai pemimpin atau "penguasa" di desa adat Guradog masih menyimpan misteri (Purnama, 2009; Rostiyati,2007; Dewantara, 2013).

Selanjutnya berdasar observasi dan wawancara kepada warga sekitar bernama Asep yang mengungkap bahwa Olot sesungguhnya memiliki tanggungjawab penuh terhadap 
keberlangsungan hidup masyarakat adat dan berperan untuk tetap menjaga nilai-nilai yang sudah menjadi tradisi dan budaya. Nilai-nilai tradisi dan budaya tersebut merupakan nilainilai peninggalan dari para sesepuh adat. Sosok yang dipilih menjadi Olot adalah sosok yang harus memahami nilai-nilai luhur yang sudah mendarah daging pada budaya masyarakatnya. Nilai-nilai tersebut terdiri dari sesuatu yang menjadi keharusan dan pantangan. Suatu keharusan merupakan nilai yang selama ini dianut oleh masyarakat. Sedangkan pantangan merupakan hal yang tidak sesuai atau menyeleweng dari kepercayaan adat setempat. Hampir sebagian besar kehidupan masyarakat adat tersebut berorientasi kepada lingkungan yang ada di sekelilingnya. Sebagai kepala adat, Abah Olot melakukan berbagai tugasnya pasti terikat pada norma sosial dan kultural yang ada, yaitu berupa tradisi yang telah diwariskan secara turun-temurun oleh leluhurnya. Demikian itu membuat masyarakat adat begitu patuh pada kebijakan-kebijakan para pemimpin adatnya. Oleh sebab itu, konstruksi yang demikian cenderung mampu dalam mempertahankan norma dan nilai sosial di tengah kehidupan adat, seperti larangan, perintah, upacara, organisasi sosial, dan lain sebagainya.

Kemudian bila melihat konteks kepemimpinan desa adat Guradog mengacu pada Purnama dan Rostiyati, Olot bukan merupakan satu-satunya pemimpin informal. Dalam menjalankan tugas dan fungsinya, ia dibantu oleh sekretaris adat, baris kolot, dan pangiwa. Ketiganya turut andil menjaga keberlangsungan budaya masyarakat adat Guradog. Cara memeroleh status sekretaris adat, baris kolot, dan pangiwa tidak berbeda dengan Olot yaitu diperoleh secara turun temurun dari tokoh sebelumnya. Sekretaris adat merupakan bagian dari jajaran pemimpin informal di desa Guradog. Sekretaris adat berperan membantu pekerjaan Olot dalam melaksanakan kegiatan-kegiatan adat seperti halnya musyawarah dan upacara adat. Untuk menghindari kesalahan dan tindakan yang sewenang-wenang, Olot memiliki baris kolot yang berfungsi melakukan pengawasan terhadap kepemimpinan Olot. Baris kolot senantiasa memberi saran dan nasihat dalam menyelesaikan permasalahan yang ada di tengah masyarakat, sedangkan pangiwa memiliki peran menyampaikan hasil musyawarah yang telah dilakukan kepada seluruh masyarakat (Purnama, 2009; Rostiyati,2007).

Atas dasar demikian, Olot selaku kepala adat bersama dengan pembantu adat merupakan sosok yang sangat dihormati dan dijadikan panutan di desa Guradog. Tugas utamanya menurut Asep adalah menjaga keselarasan nilai-nilai tradisi dan budaya dengan peraturan dan kebijakan yang dibuat oleh pemerintah formal. Ketika terjadi tindak pidana misalnya, masyarakat yang melakukan pelanggaran akan diserahkan kepada Olot dan jajarannya. Masyarakat akan lebih dulu dikenakan sanksi secara adat sebagai bentuk peringatan dan diselesaikan secara kekeluargaan sesuai dengan norma adat. Jika masalah belum dapat terselesaikan, maka akan ditindak sesuai dengan hukum negara yang berlaku. Hal tersebut bertujuan agar kedua jenis kepemimpinan dapat tetap berjalan dan masyarakat dapat hidup dalam keharmonisan. Olot menurut Rostiyati memiliki peran dalam memimpin dan mengatur seluruh aktivitas ke-adat-an. Dia dan para sesepuh adat lainnya kerapkali memberi petuah, khususnya pada acara ritual dan upacara adat. Mereka juga merupakan sosok yang dipercaya sebagai penghubung antara masyarakat dengan leluhurnya dan juga berperan menjaga kelestarian makam-makam para nenek moyangnya (Rostiyati,2007).

\section{Cara Kepala Adat Memengaruhi Kebijakan di Desa Guradog}

Pemimpin informal memiliki peranan penting dalam segala lini kehidupan masyarakat adat di Desa Guradog, di antaranya seperti memimpin segala aktivitas ritual dan menjaga kelestarian adat istiadat yang sudah membumi di tengah masyarakat desa ini. Di samping eksistensi informal leader, warga desa itu juga memiliki lembaga kepemimpinan formal seperti kepala desa (Kades) beserta aparaturnya. Tugas dan peran formal leader di antaranya yaitu mengerjakan aktivitas-aktivitas mengenai persoalan administratif tata kelola pemerintahan (contohnya pengurusan Kartu Keluarga, Kartu Tanda Penduduk dan lain sebagainya) dan 
pengelolaan kebijakan publik yang berasal dari level di atas pemerintahan desa yaitu dari mulai Camat, Bupati/Walikota, Gubernur sampai Presiden.

Pemimpin informal dalam hal ini Olot sebagai kepala adat menurut Rostiyati mempunyai peran double, yakni satu sisi sebagai pimpinan utama warga adat, sisi lainnya sebagai mediator atau agen kultural antara masyarakat adat dengan aktor pemerintah sebagai formal leader. Olot selaku kepala adat kerap menjadi suri tauladan yang berperan dalam mengelola dan melestarikan kearifan lokal (local wisdom) yang diyakini oleh komunitas adat Guradog. Bahkan dalam aktivitas kesehariannya, komunitas adat tersebut sangat berpedoman pada penuturan sang Olot. Salah satu contohnya yaitu hal-hal yang menurut kepala adat dianggap tabu, maka komunitas adat senantiasa tunduk dan patuh atas hal itu. Alhasil terlihat jelas bahwa kuasa kepemimpinan sang Olot begitu hegemonik (Rostiyati,2007).

Bila dilihat dalam kesehariannya, Olot mempunyai tugas, fungsi dan kepercayaan yang begitu signifikan dibandingkan kepemimpinan kepala desa. Hal demikian ini disebabkan karena ia memang mengatur segenap pranata dan tatanan kehidupan kemasyarakatan adat secara luas dan banyak masyarakat yang selalu melakukan sharing dan minta petunjuk kepadanya. Kepercayaan yang begitu besar dari masyarakat kepada sang Olot diyakini karena dia mampu mengokohkan dan melestarikan budaya dan adat yang diturunkan secara simultan dari para leluhur dan masyarakat Guradog percaya bahwa kepala adat dinilai punya keistimewaan (previlage) dan keutamaan serta kebijaksanaan yang lebih mumpuni dibanding dengan pihak lain. Maka dari itu Kades ataupun aparaturnya kerap mendatangi Abah Olot meminta saran, masukan dan dukungannya untuk menjalankan kebijakankebijakan pemerintah/negara di desa adat ini. Kades acapkali menunggu restunya agar program-program pemerintah dapat berjalan dan terlaksana dengan baik di desa ini. Dari hal itu terlihat bahwa Olot menjadi perantara antara pemimpin formal dengan komunitas adat.

Hal demikian itu ditegaskan juga oleh ungkapan Asep yang menyatakan bahwa ketika pemimpin formal mencanangkan dan/atau melaksanakan suatu program atau kebijakan, hal tersebut lebih dulu disampaikan kepada kepala adat dan para pembantunya, baru kemudian disampaikan kepada masyarakat. Sebelum menerapkan suatu kebijakan, masyarakat bersama pemimpin formal melakukan musyawarah. Musyawarah turut dihadiri oleh kepala adat, sekretaris adat, baris kolot, dan pangiwa. Olot beserta jajarannya selalu menghadiri rapat atau musyawarah dan selalu menjadi pimpinannya, sebab keputusannya sangat dipatuhi oleh masyarakat. Masyarakat sangat memercayai apa yang diyakini oleh abah Olot. Maka setiap keputusan dari setiap musyawarah atau rapat selalu dipengaruhi oleh persetujuan sang Olot. Artinya ia yang bukan pemimpin formal mampu membayang-bayangi aktualisasi kebijakan/program dan aktivitas keseharian yang kuasanya lebih dominatif dibanding dengan Kades, maka praktik shadow state terlihat cukup jelas.

Dalam hal memengaruhi kebijakan publik dan politik keseharian, Olot berperan sebagai mediator yang masuk ke dalam aspek institusional pemerintahan. Ia berfungsi sebagai penyampai berbagai program pembangunan. Selaras dengan itu, ia pun mempunyai peranan dalam membangun serta membantu menyebarluaskan berbagai informasi dari pembangunan tersebut kepada masyarakat adat. Jika dilihat dalam aspek hukum adat, tentunya ketua adat merupakan sumber hukum adat itu sendiri yang mengacu pada praktik kebiasaan-kebiasaan atau tradisi yang sudah lama dilakukan oleh para leluhurnya. Masyarakat adat percaya bahwa kepala adat mampu mempertahankan serta menegakkan berbagai norma tradisional dan nilai-nilai masyarakat yang sudah membumi ini.

\section{Relasi Kuasa Pemimpin Formal dengan Pemimpin Informal}

Pemimpin formal dan pemimpin informal di desa adat Guradog merupakan dua jenis kekuasaan dalam legitimasi yang berbeda. Jabatan pemimpin informal terdiri dari Olot, Sekretaris Olot, Baris Kolot dan Pangiwa. Sedangkan jabatan pemimpin formal dipegang oleh kepala desa, para ketua RW hingga ketua RT. Bila mengacu dengan tulisan Rostiyati 
yang menyebut bahwa kedua jenis kepemimpinan tersebut memiliki tugas dan kewenangan masing-masing, sehingga praktik kuasa kepemimpinan formal dengan informal di Desa Adat Guradog tidak pernah terjadi benturan kewenangan. Namun menurut sudut pandang kami justru kontestasi kuasa antar kedua aktor tersebut itu terjadi dan terlihat cukup kentara. Tanpa disadari oleh Rostiyati sebenarnya pertarungan relasi kuasa antara aktor pemimpin tersebut berlangsung dalam aktivitas keseharian dan juga realisasi kebijakan publik (Rostiyati,2007).

Pemimpin formal seperti kades biasanya bertugas mengelola program-program atau kebijakan-kebijakan publik yang dicanangkan oleh pemerintah/negara. Adapun pemimpin informal di desa adat Guradog terlihat memiliki fungsi dalam mengatur seluruh aktivitas adat dan kesakralannya serta mencakup kuasa atas aktualisasi program/kebijakan pemerintah. Dalam kerja-kerjanya, dia memiliki relasi kuasa dengan pemimpin formal. Segala bentuk kerja-kerja yang dilakukan oleh pemimpin formal akan sangat dipengaruhi oleh peran pemimpin informal di dalamnya. Kades sebagai memimpin formal memiliki programprogram pembangunan guna meningkatkan kesejahteraan masyarakat. Program-program tersebut menurut Asep dirumuskan melalui proses musyawarah yang melibatkan kepala adat beserta masyarakat. Musyawarah selalu dihadiri oleh seluruh tokoh/sesepuh adat sebagai penasihat di desa Guradog. Pelibatan kepala adat dan pembantu adat antara lain bertujuan agar terjadinya sinkronisasi antara program yang diusung pemerintah terhadap nilai dan norma yang ada di desa adat ini, serta dinilai lebih efektif karena masyarakat akan patuh dan lebih mendengarkan.

Berlandas pada Rostiyati bahwa program-program publik yang dijalankan oleh pemerintahan di level desa Guradog antara lain yaitu program keluarga berencana, kelestarian lingkungan, program kesehatan ibu dan anak, program pendidikan dan program-program lainnya. Program-program tersebut baru direalisasikan apabila sudah melalui rapat atau musyawarah yang membahas kesesuaian program dengan nilai yang dianut oleh masyarakat. Hasil musyawarah itu kemudian disebarluaskan oleh Pangiwa yang merupakan petugas adat yang berperan menyebarkan kabar mengenai proyeksi atas realisasi kebijakan/program yang sudah diputuskan kepada seluruh warga adat. Dalam menjalankan program-program publik dari pemerintah, pemimpin formal kerapkali memercayakan keberlangsungan dan keberhasilan program yang telah dibuat kepada pemimpin informal. Hal tersebut dilakukan dengan melibatkan para pemimpin informal dalam pelaksanaan program. Dilibatkannya pemimpin informal terbukti dapat menjadi penggerak dan meningkatkan antusiasme masyarakat untuk dapat terlibat aktif dalam pelaksanaan program (Rostiyati, 2007).

Dalam konteks aktivitas kesehariannya, masyarakat desa Guradog secara universal tetap berpedoman pada hukum tertinggi negara, yaitu undang-undang serta hukum pidana dan perdata di Indonesia. Namun, aktualisasinya tetap berpegang teguh pada peraturan atau hukum adat. Olot beserta para pembantu adat turut berperan serta dalam menerapkan hukum formal yang sudah ditetapkan pemerintah. Meskipun demikian Asep menjabarkan bahwa apabila terjadi pelanggaran, maka pemimpin adat akan lebih dulu memberlakukan hukum adat. Hukum adat menurut Hardjito adalah hukum yang merupakan kebiasaan masyarakat yang dijadikan sebagai pedoman hidup dalam mewujudkan keadilan dan kesejahteraan masyarakat dengan berlandaskan kekeluargaan (Abdulrahman, 1984). Hukum adat pada umumnya tidak tertulis. Hukum adat yang dimaksud adalah dengan melalui musyawarah. Musyawarah akan dilakukan bersama seluruh masyarakat yang dipimpin oleh Olot beserta jajarannya. Meskipun dapat diselesaikan secara kekeluargaan, tak jarang Olot tetap memberikan sanksi yang berlaku, tergantung pada bentuk pelanggaran yang dilakukan.

Kondisi obyektif di atas membuktikan hadirnya kuasa hegemonik pemimpin informal terhadap kepemimpinan formal. Artinya praktik shadow state tentang kuasa aktor di luar struktur formal mampu "menyetir" aktor struktural di dalam pemerintahan terejawantahkan pada kasus aktualisasi kebijakan publik dan politik kesehariannya di desa adat Guradog. Kuasa hegemonik tersebut terjadi karena adanya kepercayaan yang beredar di masyarakat 
bahwa pemimpin informal yaitu abah Olot adalah sosok yang menjadi panutan/suri tauladan bagi masyarakat desa ini. Sehingga segala tutur kata dan perbuatannya menjadi lebih mudah untuk diterima oleh masyarakat. Kuasa pemimpin informal merembes pada hampir di segala lini kehidupan masyarakat adat Guradog. Bila demikian maka praktik adat itu merupakan pranata dan tatanan atas kearifan lokal yang disinyalir akan mampu menjaga harmonisasi sosial masyarakat adat Guradog.

\section{SIMPULAN}

Kesimpulan yang dapat diambil dari penjabaran dan analisa tentang kontestasi kuasa kepemimpinan formal dengan informal di Desa Adat Guradog, Lebak, Banten adalah bahwa peranan Olot selaku kepala adat dalam kehidupan desa tersebut terlihat penting dan hegemonik karena dalam tatanan struktur organisasi pemerintahan desa, Olot menjadi sosok yang sangat disegani, dihormati dan dipatuhi dalam setiap lini kehidupan sosial, spiritual, budaya, pemerintahan dan sektor-sektor lainnya. Demikian pemimpin formal dalam hal ini kepala desa hanya menjadi sub-ordinat dari kuasa kepala adat yang terbilang dominan. Laku politik Abah Olot sebagai kepala adat menurut kesimpulan kami merupakan bukti empirik yang sesuai dengan formulasi konsep pemimpin sebenarnya (the real leader) dan sebagai aktor bayangan (shadow state) yang memiliki kuasa hegemonik di desa tersebut.

\section{DAFTAR PUSTAKA}

Abdulrahman. (1984). Hukum Adat Menurut Perundang-Undangan Republik Indonesia. Jakarta: Cendana Press.

Darmawan, I. (2006). Peran Majemuk Kepala Adat dalam Sistem Pemerintahan Desa (Penelitian di Desa Pekurun Kecamatan Abung Tengah Kabupaten Lampung Utara). Yogyakarta: Jurusan Ilmu Pemerintahan FISIP UGM.

Dewantara, A. (2013). Peran Elit Masyarakat: Studi Kebertahanan Adat Istiadat di Kampung Adat Urug Bogor. Jurnal Al-Turas, 19(2), 89-118. doi: http://dx.doi.org/10.15408/bat.v19i1.3703

Heywood, A. (2000). Key Concepts in Politics. London: Macmillan Press LTD.

Hidayat, S. (2007). Shadow State? Dalam H. d. Nordholt, Renegotiating Boundaries: Local Politics in Post-Suharto Indonesia. Leiden: KITLV Press.

Hidayat, S., \& Gismar, A. M. (2010). Good Governance Vs Shadow State dalam Penyelenggaraan Pemerintah Daerah. Jurnal Penelitian Politik LIPI, 7(1), 23-34. doi: https://doi.org/10.14203/jpp.v7i1.508

Kartono, K. (1994). Pemimpin dan Kepemimpinan. Jakarta: CV.Rajawali.

Keating, C. J. (1997). Kepemimpinan: Teori dan Pengembangannya. Penerjemah A.M. Mangunhardjana. Yogyakarta: Kanisius.

Kueng, A. V., Nasir, B., \& Budiman. (2019). Sinergitas Antara Pemerintah Desa dan Tokoh adat dalam Mempertahankan Tanah Adat: Studi Kasus Desa Lahan Kecamatan Laham Kabupaten Mahakam Ulu. Jurnal Pemerintahan Integratif, 7(3), 296-305. 
http://ejournal.pin.or.id/site/wp-content/uploads/2019/02/pin_afresius\%20(02-13-19$\underline{02-26-58) . p d f}$

Marsh, D., \& Stoker, G. (2010). Teori dan Metode dalam Ilmu Politik. Penerjemah Helmi Mahadi dan Shohifullah. Bandung: Nusa Media.

Moleong, L. J. (2014). Metodologi Penelitian Kualitatif. Bandung: PT Remaja Rosdakarya.

Purnama, Y. (2009). Kesenian Topeng Masyarakat Kasepuhan Guradog Lebak Banten. Jurnal Patanjala, 1(1), 27-41. doi: http://dx.doi.org/10.30959/patanjala.v1i1.227

Rostiyati, A. (2009). Peranan Pemimpin Informal pada Masyarakat Guradog. . Jurnal Patanjala, 1(2), 201-214. doi: http://dx.doi.org/10.30959/patanjala.v1i2.249

Soepomo. (1979). Bab-bab Tentang Hukum Adat. Jakarta: Pradnya Paramita.

Tobing, D. H. (2017). Pendekatan Dalam Penelitiaan Kualitatif. Bali: Universitas Udayana.

Yukl, G. (2007). Kepemimpinan dalam Organisasi. Penerjemah Budi Supriyanto. Jakarta: PT. Indeks.

\section{Sumber Lain:}

Wawancara langsung Tim Peneliti dengan Asep. Curugbitung, Kabupaten Lebak. November 2019. 